\title{
LANDASAN PENGEMBANGAN ETIKA DAN MORALITAS HINDU
}

\author{
Oleh \\ I Ketut Madja
}

\begin{abstract}
Abstrak
Barangkali sebelum pendidikan karakter dijadikan isu dan perbincangan di media massa, dan dalam dunia pendidikan khususnya, ada sesuatu pada saat itu yang terlupakan, tidak dipandang sebagai sesuatu yang urgen, dan akhirnya lenyap begitu saja ditelan sang waktu. Perkembangan ilmu pengetahuan dan tekhnologi yang mengglobal sedemikian rupa, kemudian menyentakan dunia pendidikan untuk bangun dari keterlupaan itu. Sebagai bagian dari pengetahuan dan kecerdasan intelektual para akhli, tekhnologi kemudian dikembangkan ke dalam bentuk yang lebih spesifik yakni tekhnologi informasi. Aspek yang tersebut terkhir ini mampu mengubah pola pikir manusia. Ada sarana yang efektif dipakai untuk menerima dan mengirim informasi dari dan kepada yang diinginkan. Informasi begitu mudah diakses setiap saat diperlukan. Menyadari kondisi actual belakangan ini, Pendidikan karakter kemudian menjadi program dalam penyelenggaraan pendidikan itu. Hal ini dipandang sebagai upaya untuk mengantisipasi kemungkinan-kemungkinan buruk yang terjadi ke depan.
\end{abstract}

Kata Kunci: Pendidikan Karakter, Etika dan Moralitas Hindu

\begin{abstract}
It is probably that before the character education is to be an issue and discussed in mass media, and specialy in education world, it is seem that there is something to be forgotten, and it does not also regarded to be an urgent thing. At last, it lost and goes together with the time. The development of knowledge and technology come to be a global thing, and surprised the education world to be aware of their forgotten. As a part of knowledge and intelectual's thinking of scienties, the technology is then developed in the specific form of technological information. The last mentioned aspect is able to change human being's attitude. There is an effective tool is used to receive and send the information from and to be wished. The information is easily accepted at any time needed. Knows the actual condition recently, the character education becomes a programme of educational institution. This is regarded to be an effort of anticipating a bad possi-
\end{abstract}

\section{Pendahuluan}

Kemajuan dalam bidang ilmu pengetahuan, kata Radhakrisnan (dalam Putra, 2014: 11) telah membawa akibat ganda bagi manusia. Pada satu sisi, ilmu pengetahuan membuka wawasan manusia, membuatnya memahami alam dengan benar, membebaskan manusia dari takhyul, membawanya ke arah kemajuan dalam segala hal. Pada sisi lain, ilmu pengetahuan yang mendasarkan dirinya pada pengamatan dan pengalaman indera, pada yang lahir, pada yang rasional (positivisme logis), sering kali mengabaikan hal-hal batin, 
yang tidak dapat dijelaskan dengan rasio.

Teknologi sekaligus memberikan harapan dan kecemasan. Teknologi merupakan tanda kemajuan peradaban manusia, tetapi sekaligus juga mengandung potensi kehancuran, demikian Radhakrishnan mengatakan (dalam Putra, 2014: 15). Sama seperti ilmu pengetahuan, teknologi juga membawa akibat ganda. Jika sisi negative ilmu pengetahuan menghancurksn fondasi keyakinan manusia, teknologi bila disalah gunakan, atau bahkan hanya bila perawatannya dilalaikan, bisa membawa bancana bagi alam dan manusia itu sendiri. Contoh ini, cukup banyak, misalnya Chernobil di Rusia, Bhopal di India, dan Fakushima di Jepang. Teknologi mengikuti ilmu pengetahuan. Makin luas wawasan ilmiah yang dicapai, makin hebat teknologi yang mampu dihasilkan. Kapak, mesin (jahit, lokomotif), tenaga nuklir adalah teknologi yang membantu manusia dari perbudakan alam, tapi sekaligus juga membebaninya dengan akibat yang tidak terduga. Dikatakan penerapan teknologi di bidang kebudayaan, misalnya, radio, televise, film termasuk media cetak, mengijinkan penyebaran pendidikan fundamental informasi tentang kebudayaan secara massal ke berbagai wilayah hampir tanpa batas. Tetapi teknologi yang sama juga membawa efek sebaliknya: pendagkalan dan penghancuran kehidupan (dalam Putra, 2014: 1617).

Dengan teknologi pertanian membawa hasil pertanian meningkat, memungkinkan manusia mengilangkan kelaparan, kemiskinan, penyakit, kebodohan. Namun bila kondisikondisi ini masih menunjukkan adanya kelaparan, penyakit dan kebodohan, di sebagian besar bumi ini, Radhakrisnan mengasalkan hal ini karena ulah manusia menyalah gunakan kemungkinan-kemungkinan teknikal dalam kepentingan social, politik dan kekuasaan dalam hubungan internasional yang salah (dalam Putra, 2014: 16).

Pemikiran Radhakrisnan ini, bila dicermati dari sisi negatifnya menyiratkan kondisi yang berpotensi sengaja atau tidak sengaja mampu menghancurkan kehidupan manusia sungguh sangat mengerikan. Lagi pula bila dilihat dari segi etika keilmuan, kesengajaan yang dilakukan untuk kehancuran itu, sungguh merupakan kekeliruan yang sangat besar pula, karena kemuktahiran teknologi yang telah digenggam sebagai ikutan kemajuan ilmu pengetahuan, telah disalah gunakan. Radhakrisnan mengatakan apa yang ia katakan disebutkan di atas, tidak bermaksud memberikan gambaran suram tentang tekologi, karena bagaimanapun teknologi sudah terbukti sangat bermanfaat, dan itu dibutuhkan oleh manusia. Ia hanya meminta agar kita menyadari bahwa manusia adalah pencipta teknologi. Karena itu harus menjadi tuan bagi ciptaannya.

Dinamika kehidupan masyarakat Indonesia saat ini dipandang sebagai riak-riak perjalanan panjang. Dalam perjalanannya telah terjadi ragam peristiwa dialaminya. Memasuki era kekinian yang penuh dengan gejolak, menjadikan masyarakatnya paling tidak - merobah pola pikir menghadapi kondisi actual yang telah terjadi dan mungkin terjadi di masa datang, karena sudah dirasakan memengaruhi segala aspek kehidupan. Kondisi ini, siap atau tidak siap mesti dihadapi, diterima dan disikapi dengan arif penuh kebijakan

Dalam dunia pendidikan dirasakan ada phenomena degradasi moral dialami peserta didik di satu sisi, dan di sisi lain bermanfaat bagi 
mereka, yakni kemajuan ilmu pengetahuan dan tekhnologi dipandang sebagai salah satu yang memengaruhi perspektif perserta didik atas kondisi kekinian tersebut, kondisi yang sepertinya siap atau tidak siap harus mereka terima dan sikapi. Peranan integratif orang tua, pendidik, lembaga pendidikan formal dan informal dominan penting dalam hal ini. Lagi pula secara spesifik kemajuan tekhnologi dikembangkan ke dalam bentuk tekhnlogi informasi, yang justru tidak kalah hebat memengaruhi generasi bangsa ini, dan peserta didik khususnya baik yang masih di tingkat pendidikan dasar, menengah, bahkan di tingkat pendidikan tinggi pun begitu santainya menyantap ragam informasi yang tersaji di media social. Ada sarana yang efektif dipakai untuk menerima dan mengirim informasi dari dan kepada yang diinginkannya. Konsekuensinya di tengah derasnya arus globalisasi komunikasi, aksesbilitas informasi begitu mudah dan ganmpang diakses setiap saat diperlukan, krisis moral pun tidak dapat dihindari.

Menyadari dampak sampingan yang tidak diinginkan, maka - kalau boleh dikatakan - pemerintah kemudian membuat kebijakan yang integrative dalam peneyelenggaraan pendidikan di tingkat dasar, menengah, bahkan pada pendidikan tinggi, dibuatkan suatu kebijakan yang mampu menopang sendi-sendi kehidupan masyarakat sehingga penerapan dari kebijakan tersebut dirasakan pula untuk kepentingan bersama semua pihak. Kebijakan itu yang seolah-olah ada ketersentakan dunia pendidikan untuk bangun dari keterlupaan akan pendidikan karakter untuk dibangkitkan dan ditumbuhkembangkan pada peserta didik. Inilah salah satu sisi baiknya perkembangan ilmu pengetahuan dan tekhnologi, mampu menggugah kepri- hatinan semua pihak dalam mengantisipasi kemungkinan-kemungkinan buruk menimpa generasi bangsa ini, meski perkembangan ilmu pengetahuan dan tekhnologi yang mengglobal merambah ke segala aspek kehidupan tidak mampu ditolak kehadirannya yang cenderung berpenomena degradasi moral.

Ada ketertarikan dirasakan para akademisi untuk membuat gagasan tentang pendidikan karakter. Menurut Yaumi (2014: 6) mengatakan pendidikan ini sesungguhnya secara tersirat telah lama dijalankan di Indonesia, hanya saja belum dirumuskan melalui indikator-indikator yang jelas termasuk definisi, karakteristik, jenis dan berbagai komponen yang membangun satu kesatuan yang utuh. Dikatakan (Yaumi, 2014: 3), secara akademis gagasan untuk melaksanakan pendidikan karakter yang diprakarsai oleh Kementerian Pendidikan Nasional pada 2010 memberi inspirasi baru bagi para ilmuwan pendidikan, akademisi, dan praktisi pendidikan di Indonesia untuk menelaah lebih jauh disamping mengkaji secara komprehensip tentang konsep dan teori yang berkenaan dengan pendidikan karakter tersebut. Bahkan sebagaian pakar pendidikan telah memasukan konsep pendidikan karakter dan budaya di dalamnya.

Pada 14 Januari 2010, diselenggarakan sarasehan nasional tentang pengembangan pendidikan budaya dan karakter bangsa. Sarasehan ini dipandang sebagai modal kolektif bagi pengambil kebijakan untuk merumuskan sejumlah konsep dasar pendidikan budaya dan karakter, yang pada saat itu dirasakan masih menyisakan sejumlah pertanyaan klasik tentang pendidikan dimaksud, seperti; apa sebenarnya yang dimaksud dengan pendidikan budaya dan karakter, mengapa pentingnya pendidikan 
budaya dan karakter bangsa, dan bagaimana inplementasinya dalam kontek pedidikan nasional (Yaumi, 2014 : vi). Atas dasar persoalanpersoalan seperti itu, kemudian dibuatkan landasan-landasan untuk mengembangkan pendidikan tersebut. Untuk menggali nilai-nilai karakter, yang perlu dikembangkan, adalah landasan moral, etika dan agama menjadi perhatian dalam kebijakan tersebut, di samping landasan lainya. Titik tolak pengembangan landasan ini adalah bermula dari adanya prakarsa Kementerian Pendidikan Nasional pada 2010.

Telahaan tulisan ini mengacu pada landasan moralitas, dan etika Hindu dalam pendidikan karakter peserta didik dipandang bisa berkotribusi positif mendukung pendidikan nasional, disamping sebagai kekuatan mendasar dan pijakan yang kokoh dalam mengembangkan keperibadian perserta didik. Bagaimana sesungguhnya konsep-konsep ajaran agama Hindu terkait dengan aspek moralitas, dan etika Hindu bagi pendidikan karakter peserta didik. Artinya bahwa relevansitas aspek moralitas dan etika sebagai bagian dari ajaran agama Hindu berpotensi untuk mengembangkan karakter peserta didik.

\section{Pembahasan}

\subsection{Pendidikan karakter}

Eksistensi pendidikan karakter belakangan ini semakin menampakkan dirinya sebagai yang diperhitungkan dalam kasanah pendidikan generasi bangsa ini, apalagi mengacu pada pendapat Muhammad Yaumi (2014: 5) mengatakan bahwa pendidikan karakter telah lama dianut bersama secara tersirat dalam penyelenggaraan pendidikan nasional. Pendapat ini - kalau boleh dikatakan - mengandung makna bahwa pendidikan karakter sebagai bagian dari upaya penyelenggaraan pendidikan nasional, semestinya dimanfaatkan sebagai peluang untuk. bagaimana komponen-komponen yang terlibat dalam dunia pendidikan memerankan dirinya secara integrative mengembangkan karakter peserta didik. Optimalisasi keberhasilan tentang hal ini rupanya belum sepenuhnya kelihatan. Oleh karena itu tidak mengherankan kalau pendidikan karakter yang unsur-unsurnya menurut Muhammad Yaumi - sejatinya telah dirumuskan dalam tujuan pendidikan nasional sejak Indonesia merdeka hingga sampai sekarang ini. Tersirat dalam pernyataan ini kalau urgensitas unsur-unsur pendidikan karakter yang terkandung di dalam pendidikan karakter itu sendiri, perlu ditindaklanjuti. Hal ini penting mengingat kondisi kehidupan berbangsa dan bernegara pada umumnya dan dunia pendidikan bangsa ini khususnya, telah menampakkan kecenderungan perubahan pola pikir dalam menghadapi perkembangan dan kemajuan ilmu pengetahuan dan tekhnologi dewasa ini.

Pendidikan adalah aktivitas dan usaha manusia untuk menigkatkan kepribadiannya dengan jalan membina potensi-potensi pribadi, yaitu rokhani (pikir, karsa dan rasa, cipta dan budi nurani, serta jasmani (pancaindera dan keterampilan-keterampilan) (Tim, 1980: 7). Menurut F.W.A Frobel (dalam Soejono, 1978: 53) menginginkan pendidikan yang harmonis, karena pendidikan itu bertujuan berkembangnya manusia utuh dengan segala daya jasmani dan rokhani yang ada padanya. Pendidikan itu wajib sesuai dengan kebutuhan hidup sekarang dan yang akan datang, agar anak dapat hidup murni, memenuhi panggilannya di dunia ini sebagai makhluk yang berasal dari Tuhn dan 
kembali menuju Tuhan.

Mencermati definisi pendidikan seperti diuraikan di atas dapat dikatakan bahwa pendidikan adalah segala usaha sadar dilakukan pendidik untuk mengembangkan segala potensi jasmani dan rokhani peserta didik, agar terbentuk pribadi-pribadi yang utuh baik dalam kecerdasan intelektual maupun kekokohan iman yang diperoleh dari pendidik. Hasil dari pedidikan itu hendaknya mencerminkan keseimbangan antara kecerdasan intelektual dengan kekuatan iman yang dihasilkan dari pendidikan itu. Secara sosiologis, hasil dari pendidikan itu sangat menentukan eksistnesi suatu masyarakat. Keadaan masyarakat dapat diukur melalui berhasil atau tidaknya pendidikan. Karena itu, menurut Plato kebobrokan suatu masyarakat tidak dapat diperbaiki dengan cara apapun, kecuali dengan pendidikan. Untuk hal itu, perlu adanya rumusan tentang tujuan yang akan dicapai oleh pendidikan yang dilakukan. Sesuatu yang dipandang baik akan menjadi arah semua hal, sesuatu yang dikejar, sesuatu yang dituju. Sedangkan definisi baik, menurut Aristotels (dalam Poespoprojo, 1999: 34) sebagai sesuatu yang untuknya hal itu dikerjakan. Tersebut dalam Undang-Undang No. 2/1989 Pasal 4 dijelaskan tentang tujuan pendidikan sebagai berikut.

"Pendidikan nasional bertujuan mencerdaskan kehidupan bangsa dan mengembangkan manusia Indonesia seutuhnya, yaitu manusia yang beriman dan bertakwa terhadap Tuhan Yang Maha Esa dan berbudi pekerti luhur, memiliki pengetahuan dan keterampilan, kesehatan jasmani dan rohani, kepribadian yang mantap dan mandiri serta rasa tanggungjawab kemasyaraktan dan kebangsaan".

Berpijak pada rumusan tujuan pendidikan ini, tentu telah dipandang sebagai sesuatu yang baik, dijadikan arah untuk bisa sampai pada tujuan, oleh karena itu ia patut dipedomani dan diimplementasikan demi memanusiakan manusia yang seutuhnya, cerdas intelektual, kokoh dalam iman dalam menjalankan ajaran agama. Bahkan kedinamikaan perjalanan kehidupan bermasyarakat dan berbangsa dirasakan semakin cenderung mengalami perkembangan ke arah yang lebih komplek, maka dikeluarkan UU No.2 Tahun 2003, tentu tanpa maksud mengenyampingkan Undang-Undang yang diberlakukan sebelumnya. UU No.2 Tahun 2003 berbunyi sebagai berikut.

Pendidikan nasional berfungsi mengembangkan kemampuan dan membentuk watak serta peradaban bangsa yang bermartabat dalam rangka mencerdaskan kehidupan bangsa, bertujuan untuk berkembangnya potesi peserta didik agar menjadi manusia yang beriman dan bertakwa kepada Tuhan Yang Maha Esa, berakhlak mulia, sehat, berilmu, cakap, kreatif, mandiri, dan menjadi warga negara yang demokratis serta bertanggug jawab".

Jadi menurut Jalaludin dan Abdullah Idi, (2017: 205) "produk" pendidikan nasional yang diharapkan, tidak hanya diharapkan cerdas, dan pintar tetapi berakhlak, bermoral, dan berkarakter, sehingga mereka (peserta didik) bisa hidup dalam zamannya di era global ini.

Terkait dengan karakter, Bagus (2000: 392) karakter dalam bahasa Inggris "character" dalam bahasa Yunani 'charakter'" turunan dari kata "charassein" yang berarti "membuat tajam", "membuat dalam". Dikatakan bahwa karakter sangat jelas terungkap melalui kegiatan social dan kegiatan 
kerja, melalui pola tindakan-tindakan manusia. Di situlah ia berpautan dengan seluruh perilaku individu. Ia dari sifatnya yang sosio-psikologis dipengaruhi oleh pandangan terhadap dunia yang dimiliki seseorang, pegetahuan dan pengalamannya. Ia juga dipengaruhi oleh prinsip-prinsip moral yang diterima, oleh bimbimbingan orang lain, dan interaksi aktif dengan mereka. Definisi lain karakter adalah nama dari seluruh ciri pribadi yang meliputi hal-hal seperti perilaku, kebiasaan, kesukaan, ketidaksukaan, kemampuan, kecenderungan, potensi, nilai-nilai, dan pola pemkiran. Dalam pengertiannya yang lebih umum, karakter adalah sikap manusia terhadap lingkungannya yang diekspresikan dalam tindakan (Yaumi, 2014: 7).

Dari definisi-definisi karakter tersebut dapat disimpulkan bahwa karakter merupakan kumpulan dari beberapa aspek kepribadian seseorang yang diekspresikan dalam bentuk tindakan. Bermoral ataukah amoral tindakannya bukan menjadi persoalan, karena hal tersebut belum mendapat sentuhan dari lingkungan sekitar. Itulah ciri-ciri tertentu yang sudah menyatu pada diri seseorang yang ditampilkan dalam bentuk prilaku. Oleh karena itu perlu adanya pendidikan karakter (character education) untuk meluruskan prilaku amoral sesuai dengan norma-norma yang berlaku di lingkungannya, misalnya di dalam keluarga, sekolah, dan masyarakat. Di lingkungan inilah akan terjadi interaksi aktif, bimbingan, sehingga prinsipprinsip moral di lingkungan ini bisa diterima.

Dengan demikian,terkait dengan pendidikan karakter adalah usaha yang sengaja dilakukan dan diberikan secara sadar dari seorang pendidik yang berkompeten di bidangnya untuk membentuk dan mengembangan segala potensi jasmani dan rohani peserta didik, sehingga menjadi manusia yang sehat, berpengetahuan, cerdas, berkepribadian mantap, terampil, bermoral, dan bertanggung jawab. Produk seperti inilah sesungguhnya menjadi tujuan Pendidikan Nasional yakni memanusiakan manusia yang manusiawi seutuhnya.

\subsection{Etika dan Moralitas}

2.2.1 Dalam pengertian aslinya, apa yang disebut baik itu ialah sesuatu yang sesuai dengan kebiasaan masyrakat saat itu. Lambat laun pengertian etika itu berubah, seperti yang dipahami sekarang ini. Hal ini bila dilihat dari istilah Etika berasal dari kata Latin: Ethic (us), dalam bahasa Greek; Ethikos = a body of moral principle or value (Salam, 2000; 3). Maksudnya sebenarnya ialah kebiasaan, habit, custom. Jadi dalam pengertian aslinya, ialah seperti tersebut di atas.

Pengertian etika seperti yang dipahami sekarang ini ialah suatu ilmu yang membicarakan masalah perbuatan manusia, mana yang dapat dinilai baik, dan mana yang jahat. Titik berat penilaian etika sebagai suatu ilmu ialah pada prilaku baik, jahat diperbuat manusia. Telah dimengerti secara luas bahwa perilaku etis menyangkut perbuatan dalam kerangka baik dan benar, bahkan perbuatan jahat pun telah diketahui setiap orang, sehingga timbul darinya perilaku tidak etis, menyangkut kurang atau tidak baik (jahat). Etika menyangkut sikap manusia terhadap hidup. Manusia diharapkan beperilaku yang baik, memiliki disiplin, tidak melakukan perbuatan jahat. Peraturan untuk bertingkah laku yang disebut orang tata susila, adalah nama lain dari etika (Sura, 1985: 38). Etika adalah 
bentuk pengendalian dalam pergaulan hidup bersama. Oleh karena itu perlu dibuatkan peraturan dalam pergaulan hidup bersama tersebut. Tujuannya ialah untuk mengendalikan setiap perilaku tidak baik individu yang ada dalam kebersamaan itu.

Dilihat dari bentuk jamak kata "ethos" adalah "ta etha" yang berarti adat istiadat. Ia (etika) sama dengan moral, dari bahasa Latin "mos" (jamaknya "mores") yang berarti kebiasaan atau adat. Jadi pengertiannya sama dengan "ta etha" atau "ethos" yaitu adat istiadat. Dengan latar belakang pengertian yang sama seperti itu, maka sudah sejak zaman dahulu istilah etika dipakai untuk menunjukkan filsafat moral. Kemudian W.J.S Purwadarminta 1966 (dalam Suhardana, 2006:1) etika diartikan sebagai ilmu tentang apa yang biasa dilakukan atau ilmu tentang adat kebiasaan atau sebagai ilmu pengetahuan tentang asas-asas akhlak atau moral, Dengan demikian dalam kaitannya dengan dunia ilmu, etika adalah ilmu pengetahuan menjelaskan tentang apa yang baik dilakukan, dan apa pula yang buruk tidak dilakukan. Ia cenderung berbicara tentang hak dan kewajiban moral, sebagai kumpulan nilai tentang akhlak (moral), benar dan salah yang berlaku dalam suatu kehidupan masyarakat atau golongan. Sehubungan dengan perilaku seseorang yang telah diikat oleh peraturan dalam suatu masyarakat, maka istilah lain dari etika disebut tata susila. Menurut I Gede A.B Wiranata SH., MH (dalam Suhardana, 2006: 4) mengartikan antara lain etika adalah ilmu tentang kesusilaan yang menentukan bagiamana seharusnya manusia hidup dalam masyarakat mengenai apa yang baik dan apa yang buruk. Etika kadangkala disebut moral karena ia merupakan prinsip perilaku manusia. Studi mengenai hal ini disebut filsafat moral. Oleh karena itu filsafat moral merupakan cabang ilmu fisafat yang berkaitan dengan karakter yang merupakan studi untuk membedakan yang benar dari yang salah dan yang baik dari yang buruk.

Hidup bersama dalam suatu masyarakat pada umumnya diikat oleh ketentuan atau peraturan yang telah disepakati. Ada tolok ukur atau patokan yang dipakai untuk menilai sesuatu.Tujuannya adalah untuk kepentingan, dan kebersamaan setiap bentuk tindakan bagi mereka yang eksis di dalam masyarakat atau golongan itu, hidup yang tertib, teratur, aman dan tentram. Bila aturan itu bersentuhan dengan ranah yang normative, hal itu berarti tindakan-tindakan mereka harus didasarkan dan sejalan pada dan dengan norma-norma yang ada di masyarakat itu. Perilaku seperti ini dikatakan perbuatan atau tindakan bermoral, perilaku yang bernorma moral, sebagai lawan dari tindakan immoral. Meskipun sementara ini ada persepsi norma moral merupakan ketentuan yang memberikan kebebasan kepada manusia bertindak sesuai dengan kesadaran dan rasa tanggung jawabnya, hal itu tersirat ada kesadaran moral tanpa paksaan untuk melakukan sesuatu. Bagi kesadaran moral yang patuh terhadap norma yang telah dipakai sebagai bentuk peraturan, maka pandangan mengenai kesadaran moral seperti itu berbeda dengan "norma" sebagai sebuah peraturan, walaupun samasama berbicara mengenai normal 
moral.

Menyangkut moralitas menyiratkan adanya suatu yang mencirikan kualitas kemoralan yang ditampilkan seseorang dalam lingkungannya yang telah diikat oleh norma moral. Moralitas mengekspresikan kebenaran atau kesalahan, kebaikan atau ketidakbaikan dari perbuatan-perbuatan manusiawi. Adakah perbuatan seseorang telah memiliki kualitas moral, sifat benar atau salah? Apabila suatu perbuatan dipandang menurut hakikatnya bebas dari keterikatan norma moral, hal itu menandakan moralitas yang intrinsik. Artinya yang dipandang hanya baik atau buruknya perbuatan itu, bukan pada perbuatan itu dilakukan atas perintah atau larangan dari seseorang lain. Sebaliknya moralitas ekstrinsik memandang perbuatan yang dilakukan sesorang bukan saja atas perintah atau larangan dari seseorang yang memiliki kewenangan dalam kontek norma moral, tapi juga berasal dari perintah atau larangan Tuhan. Dengan demikian, siapapun mereka yang memang telah hidup dalam kebersamaan, diikat oleh norma moral, adat istiadat atau kebiasaan tertulis mapun tidak tertulis, apalagi bersumber dari ajaran-ajaran etika yang dinyatakan kitab suci, semestinya menerapkan kualitas moralnya.

\subsubsection{Etika dan Moralitas Hindu}

Betapa sangat mulianya setiap aspek ajaran agama yang dianut umatnya. Karena percaya dan yakin terhadap ajaran-ajaran agamanya, dipergunakanlah kemudian ajaranajaran itu sebagai pedoman dan landasan untuk berlaksana. Umat Hindu dalam keseharian hidupnya berpikir, berucap, dan berbuat, senantiasa dilandasi oleh ajaran-ajaran aga- ma Hindu, terbingkai dalam tiga kerangka dasar agama Hindu yakni: Tattwa atau Filsafat, Susila atau Etika dan Upacara atau Ritual agama Hindu. Tiga aspek ini dipandang sebagai satu kesatuan yang utuh tidak bisa dipisahkan satu dengan yang lainnya. Pemahamannya harus seimbang, tidak semata pada aspek upacara, atau etika, tetapi aspek filsafatnya ditinggalkan. Adanya doktrin agama Hindu seperti ini tentu adanya sumber utamanya, tiada lain kitab suci Weda atau kitab-kitab suci agama Hindu lainnya. Prinsipnya kitab suci agama Hindu dipakai landasan berbuat, berperilaku etis, dan moralitas umat Hindu.

Meyangkut tentang etika atau moralitas dalam agama Hindu dapat ditelusuri dari istilah lain dari etika atau moralitas itu sendiri. Etika atau moralitas agama Hindu menurut (Suhardana, 2006: 19) dinamakan "susila". Kata "susila" berasal dari kata "su" dan "sila". Su artinya baik, dan sila berarti kebiasaan atau tingkah laku perbuatan manusia yang baik. Karena itu, dalam agama Hindu etika dikatakan sebagai ilmu yangt mempelajari "tata nilai", tentang baik dan buruknya suatu perbuatan, apa yang harus dikerjakan atau dihindari, sehingga teripta hubungan yang baik diantara manusia. Etika adalah tata laku atau perbuatan yang baik, dan biasanya disebut "sila". Ilmunya dinamakan ilmu tentang sila atau tata susila. Salah satu aspek dalam ilmu etika adalah membahas aspek moral dan arti apa yang baik dan tidak baik.

Mencermati penjelasan di atas, dapat dikatakan bahwa etika atau moralitas dalam agama Hindu sesungguhnya juga mencerminkan kualitas moral manusia yang dit- 
ampilkan dalam bentuk perilaku dan tindakan. Terwujudkah moral yang baik dalam perbuatan itu sesuai dengan norma yang telah ditetapkan, dan adat kebiasaan, ataukah sebaliknya? Dilihat dari istilah lain dari etika atau moralitas dalam agama Hindu seperti diuraikan di atas, menunjukkan bahwa memang sebaiknya ada peraturan tingkah laku yang baik, yang mampu menata hubungan yang harmonis, selaras, serasi di antara sesama manusia, dan manusia dengan lingkungannya, karena kondisi inilah yang dikehendaki dan menjadi tujuan "tata susila" itu sendiri. Dengan demikan tata susila berarti peraturan tingkah laku yang baik dan mulia yang harus menjadi pedoman hidup manusia (Mantra, 1993: 5). Beranjak dari pemahaman ini, dengan tegas dikatakan tujuan tata susila adalah untuk membina perhubungan yang selaras atau perhubungan yang rukun antara seseoramg dengan makhluk yang hidup di sekitarnya, selaras antara keluarga yang membentuk masyarakat dengan masyarakat itu sendiri, bangsa dengan bangsa yang lain.

\subsubsection{Landasan Etika dan Moralitas dalam Agama Hindu}

Umat Hindu pada umumnya melandasi hidup dan kehidupan etis dan moralitasnya pada ajaran-ajaran agama Hindu itu sendiri. Pedoman yang dipergunakan adalah kitab suci Weda dan kitab-kitab suci agama Hindu lainnya. Landasan etika dan moralitas agama Hindu dimaksud dapat dilihat dalam beberapa kitab suci agama Hindu, antara lain seperti tersebut di bawah ini.

\subsubsection{Dalam Kitab Suci Weda}

Sesuai dengan ketentuan, setiap agama yang resmi diakui keberadaannya, harus memiliki kitab suci sebagai pedoman hidup umatnya. Agama Hindu yang dalam kontek landasan etika dan moralitas, dapat dilihat antara lain dalam kitab Suci Atharvaveda III.30.4 (dalam Suhardana, 2016: 81-82) sebagai berikut.

Yena Devā na viyanti

no ca vidvișate mithah

tat krnmo brahma vo grhe

Samjñ̄anam puruṣebhyah

Artinya

Wahai umat manusia

Persatuan akan menyatukan para

Dewa

Tuhan juga memberikan hal yang sama kepadamu

Sehingga kamu pun akan bersatu juga.

Memperhatikan sloka di atas menunjukan keserasian jalan menuju kerukunan. Hal ini berarti dengan keserasian hidup, kemakmuran dan persatuan akan dapat dicapai. Keserasian hendaknya dirintis dalam lingkungan keluarga, dalam masyarakat sekitar. Keserasian menjadikan kita hidup rukun dan damai.

Rgveda I. 114.7 (dalam Suhardana, 2016: 70-71) disebutkan: Māna ukșantam uta mā na ukșitam. Artinya: Janganlah menyakiti orang -orang muda dan orang-orang tua.

Mā no vadhih pitaram, mota mātaram. Artinya: Janganlah mencelakai ayah bunda kami

Rgveda I.114.8 disebutkan: $M \bar{a}$ nas toke tanaye māna āyau. Maksudnya: Janganlah menyakiti anak cucu dan anggota keluarga kami.

Bila dicermati sloka-sloka tersebut terkait dengan ajaran ahim$s a$ atau tanpa kekerasan. Ini berarti 
memberi tuntunan kepada manusia tidak boleh menyakiti hati siapapun juga, dan jangan mengganggu atau merugikan orang lain. Menyadari dasar semua makhluk, itu berarti tiap-tiap perbuatan yang baik dan yang tidak baik, yang dilakukan seseorang pada orang lain, berarti juga berbuat baik atau tidak baik kepada diri sendiri. Jika seseorang menyadari ini, maka ia akan senatiasa berbuat baik untuk semua makhluk. Inilah menurut agama Hindu disebut dengan ajaran Tat twam asi, Atman Brahman Asmi. Namun manusia pada umumnya jarang menyadari hal kebenaran itu, oleh karena itu perlu adanya peraturan tata susila, yang pada pokoknya menghalangi perbuatan menyiksa makhluk lain dan juga diri ssendiri.

\subsubsection{Dalam kitab Sarasamus- ccaya}

Ada beberapa sloka yang menyiratkan tujuan hidup menjadi manusia, seperti yang dikutip oleh Suhardana (2016: 145), antara lain sloka 2 kitab dimaksud disebutkan:

Mānusah sarvabhūteșu

varttate vai șubhāśubhe

aśubheșu samaviștam

śubhesvevā vakārayet

Artinya

Dari semua makhluk yang hidup

Hanya manusia yang dapat berbuat baik dan buruk

Peleburan perbuatan yang buruk menjadi baik

Hanya dapat dilakukan oleh manusia, dan itulah manfaatnya menjadi manusia.

\section{Sloka 6}

Sopanabhutam svargasya

manusyam

prāpya durlabham

tathāmānam samādyad dhva setana purna yatha (dalam Suhardana, 2016: 146)

Artinya

Manfaatkanlah kesempatan menjadi manusia karena sangat sulit untuk diperoleh laksana meniti tangga menuju sorga pegang teguh semua penyebab kejatuhan.

Sloka 17

Yathāyathā hi puruṣah

kalyāna ramate manah

tathā tathāsya suddhayanti

sarvvārtha nātra sampșayah

(dalam Suhardana, 2016:147)

Artinya

Semua orang baik golongan

rendah

Golongan menengah maupun

tinggi

Selama berbuat baik sebagai hobinya

Tercapailah segala hal yang diinginkan.

Sloka 34

Eko dharmanah pram creya

kșamaika snticucyate

vidyaika paramā tuṣtir

ahisaikā sukhāwahā (dalam

Suhardana, 2016: 148)

Artinya

Hanya dharma merupakan kebenaran dan kewibawaan

Hanya ketentraman pikiran merupakan ketahanan

Terhadap panas dan dingin yang dapat jadi obat

Sebagai penyuci dan pemadam penderitaan.

Pikiran yang diekspresikan dalam perkataan dan perbuatan sering memberikan gambaran pada penampilan seseorang. Oleh karena itu pikiran yang diibaratkan sebagai kuda liar, bagaimanpun harus dikendalikan agar tidak cenderung tertuju pada yang merugikan orang lain dan diri sendiri. Pikiranlah 
merupakan unsur yang menentukan, bila penentuan perasaan hati telah terjadi, maka mulailah orang berkata, atau melakukan perbuatan. Sloka -sloka Sarasamucaya menyebutkan seperti berikut ini.

Sloka 74

Anabhidhyām parașvesu

Sarvasatvesu cārușam

Karmaņām phalamastīti

Trividham manāsa aret

Artinya

Tindakan dari gerak pikiran

Tidak ingin dan dengki pada kepunyaan orang lain

Tidak gemas pada semua makhluk

Percaya pada ajaran karmaphala

Sloka 75

Asatpralāpham pārusyam

paicunyamanrtam tatha

vatvāri vācā rājendra

najalpennānucintayet (Kajeng, 1997:65)

Artinya

Inilah yang tidak patut timbul dari kata-kata

Perkataan jahat

perkataan kasar dan menghardik

perkataan menfitnah

perkataan bohong

\subsubsection{Dalam Slokantara}

Setiap orang senantiasa ingin hidup bahagia. Bahagia dalam arti mendapatkannya dengan jalan dharma. Kebahagiaan yang diperoleh dengan tidak berdasarkan ajaran agama, akan senantiasa membawa ketidak tenangan dalam diri seseorang yang melakukannya. Maka berupayalah memperoleh kebahagiaan itu atas dasar antara lain suka menolong, berbicara, berkata, dan berbuat tidak menyakiti orang lain, bijaksana, ramah dan selalu berbakti kepada Tuhan.

\section{Sloka 10}

Sarvamapuspam prthiwin bhunjnti catwāro narāh

upāyajnacca curacca

krtawidyah priyamwadah

(Agung Oka, 1993: 25)

Artinya

Ada empat golongan manusia

yang menikmati kebahagiaan

hidup di dunia

Orang yang tahu tujuan dan cara

hidup

Orang yang pemberani, bijaksa-

na

Orang yang pandai berbicara dan ramah

Ajaran dharma yang senantiasa dilakukan seseorang akan terhindar dari neraka. Sorga adalah alam akhirat yang menyenangkan. Berupayalah untuk memperolehnya. Berbuat di jalan dharma, memilah dan memilih antara yang baik dan yang jahat adalah cara untuk memperolehnya. Sloka 5 Slokantara disebutkan;

Trmakuncanuditanam kancanaih kim mrganam

phalatarumuditanam ratbhir wanaranam

asuradhimiditanam gandhibhih sukaranam

naca bhawati naranam tu pryam tad wicenam (Agung Oka, 1993: 14)

Artinya

Seekor rusa bahagia karena rumput, bukan karena emas

Kera bahagia karena buahbuahan, bukan karena mutiara

Babi gembira karena diberi makan yang busuk, bukan karena bunga harum. Bagi manusia berbuat baiklah yang utama.

\subsubsection{Dalam Canakya Niti Sastra}

Manusia berpikir karena ia ada, karena merasa ada manusia tidak bisa tidak berpikir. Itulah hakikat manusia hidup untuk berpikir. Perlu kecermatan, ketelitian, kekritisan memandang 
hidup dan kehidupan yang penuh objek memengaruhi pikiran. Berpikirlah dengan baik sebelum berbuat sesuatu. Canakya Niti Sastra sloka 2 (dalam Suhardana, 2006: 239) disebutkan;

Drstiputam nyasetpadam

vastra putam pibejjalam

sastra putam vaded vakyam

manah putam samasaret

Artinya

Lihatlah dulu dengan teliti baru berjalan. Jika minum air, saringlah dulu. Mengerti dulu Kitab Suci, baru berbicara. Pikirkan dulu matangmatang baru berbuat.

\section{Simpulan}

Kutipan sloka-sloka yang terdapat dalam kitab suci agama Hindu, sesungguhnya merupakan landasan ajaran etika dan moralitas bagi umat Hindu. Hal ini perlu dikembangkan dan disesuaikan dengan pertumbuhan dan perkembangan peserta didik.

Perkembangan merupakan proses atau tahapan pertumbuhan ke arah yang lebih maju yang bersifat psikis. Ada perubahan mental yang berlangsung secara bertahap dan dalam waktu tertentu, dari kemampuan yang sederhana menjadi kemampuan yang lebih sulit. Misalnya kecerdasan, sikap dan tingkah laku.

Pertumbuhan (growth) merupakan tahapan peningkatan sesuatu dalam hal jumlah, ukuran, dan arti pentingnya. Pada peserta didik, ia lebih bersifat pisik (Susanto, 2011: 21). Dipengaruhi oleh factor bakat (genetic), lingkungan, dan konvergensi (perpaduan) bakat dan lingkungan. Oleh karena itu, diperlukan kemampuan metode pengembangan yang efektif dan praktis terhadap landasan etika dan moralitas bagi karakter peserta didik.

\section{Daftar Pustaka}

Agung Oka, I Gusti, 1993. Slokantara.
Jakarta: Hanuman Sakti

Bagus, Loren, 2000. Kamus Filsafat. Jakarta. PTGrafindo.

Kajeng, I Nyoman. Dkk.1997. SARASAMUCCAYA Dengan Teks Bahasa Sansekerta dan Jawa Kuna. Jakarta: Hanuman Sakti

Jalaluddin.H. dan Abdullah Idi.H. FILSAFAT PENDIDIKAN Manusia, Filsafat, dan Pendidikan. Depok: PT RajaGrafindo Pustaka

Poespoprodjo. W. 1999. FILSAFAT MORAL Kesusilaan dalamTeori dan Karakter. Bandung: CV Pustaka Grafika.

Putra Ngakan, Putu, 2014. KAMU ADALAH TUHAN Manusia Dalam Agama Hindu. Media Hindu.

Salam, Burhanuddin, 2000. ETIKA INDIVIDUAL Pola Dasar Filsafat Moral. Jakarta: PT Renika Cipta.

Soejono. Ag. 1978. Aliran Baru Dalam Pendidikan. Bandung: Angkasa Omset.

Pengantar Dalam Bebagai Aspeknya. Rawamangun - Jakarta: PT Tambra Raya

Suhardana, Km. 2006. PENGANTAR ETIKA \& MORALITAS Bahan Kajian untuk memperbaik tingkah laku. Surabaya: Paramita.

Sura, I Gde, 2001. PENGENDALIAN DIRI DAN ETIKA Dalam Ajaran Agama Hindu. Hanuman Sakti.

Tim Dosen FIP-IKIP Malang.1980. Pengantar Dasar-dasar Pendidikan. Surabaya- Indonesia: Usaha Nasional.

Yaumi, Muhammad, 2014. PENDIDIKAN KARAKTER Landasan, Pilar, dan Implementasi. Karisma Putra Utama. 